\title{
The Protected Areas Network in Sicily, Italy: a new opportunity for territorial development
}

\author{
S. Privitera ${ }^{1} \&$ N. Quercio ${ }^{2}$ \\ ${ }^{1}$ CUTGANA, Centro Universitario per la tutela e la gestione degli \\ ambienti naturali e degli agro-ecosistemi, Università di Catania, Italy \\ ${ }^{2}$ Laboratory L.A.Co.S.T.A., University of Molise, Italy
}

\begin{abstract}
Protected areas are becoming a new land connotation not only linked to the conservation of biodiversity and the protection of the environment but also to their ability to ensure sustainable local development, in compliance with various local identities of the surrounding territories. In this context, the development of slow mobility inside the protected areas can be an opportunity for progress and growth because it could be able to intercept the increasing requests for green tourism. Slow mobility, declined within protected areas, can contribute not only to safeguarding the environment and the health of populations, favouring one type of careful use, but also offers the opportunity of to recover old paths that can be restored as greenways to favour slow mobility, and historical artefacts found along their path to fruition by sustainable tourism. The case study presented in this paper is the protected area "Riserva Naturale Orientata Pantalica, Valle dell'Anapo e Torrente Cava Grande" as an example of an area where there are various types of soft mobility. In particular, the sign of the path of one of the most important historical sites in the valley - the old railroad Syracuse-Vizzini - is analyzed. In light of the presence of multiple valuable elements, the Region of Sicily has developed an instrument known as a "landscape integrated route", in order to draw up a "matrix of development" of this area.
\end{abstract}

Keywords: protected areas, slow mobility, greenways, landscape. 


\section{Introduction}

In the present paper, the territory of the selected Nature Reserve of Pantalica is investigated through analysis of interventions undertaken for the development, especially linked to the utilization of a railway path which is no longer in use.

Transportation and mobility represent one of the most interesting challenges for the recovery of living spaces especially in an urbanized environment. Moreover, interventions in areas that already have high environmental intrinsic values, such as natural areas and especially protected areas, are very interesting.

In the examined case study, one of the most striking measures of enhancement of an ancient thoroughfare was created. This constitutes an interesting example from a territorial point of view, since it fits into an area which is already bound, because it was declared, in different ways, to be of significant public interest (in this territory different restriction decrees are in place, but especially due to the fact that this area was tied in 1998 with the Declaration of high public interest of the High Valley of the Anapo River, hanging in the municipalities of Buccheri, Buscemi, Carlentini, Cassaro, Ferla, Palazzolo Acreide and Sortino) [1-6]. This study is focused, therefore, on the Anapo River Valley located in eastern Sicily, in an area of interest - although an even more internal area - even from the Iblei National Park proposal [7, 8]. The study zone is of great interest due to the presence of its archaeological and architectural heritage [9]. It is also to be highlighted that it is one of the most outstanding areas in terms of scenic landscape of the whole of Sicily. It comprises the Anapo River, where the valley has been deeply eroded to become a canyon up to the gorges of Pantalica, where one of the largest prehistoric (from the Late Bronze Age) Sicanians necropolis in the Mediterranean region is located, with some 5000 rock-cut chamber tombs. In this area, there is still signs of one of the most important historical heritage sites of the valley; the old railway line Syracuse-Vizzini. Precisely in the light of the simultaneous discovery of many valuable items, an "integrated landscaped path" was designed by the Sicily Regional Government in order to build a "matrix of development" of the territory that it comprises [10]. Figure 1 shows the study area, with reference to the territory of the region and of the Province of Syracuse.

\section{The system of protected areas in Sicily}

In the late 70 s of the last century, tons of cement and a hundred thousand illegal constructions covered relentlessly a large part of the Sicilian territory with designs for public and private works which were carried out in areas of great environmental and naturalistic interest. This prompted a strong sense of rebellion which crossed the island's civil society and, thus, gave rise to a spontaneous movement of citizens who opposed, with strength, passion and determination, the execution of these works.

It was the civil fight against the construction of a coastal road that would have connected the towns of San Vito Lo Capo and Scopello Village and would have forever marred one of the most scenic stretches of coastline and spectacular 


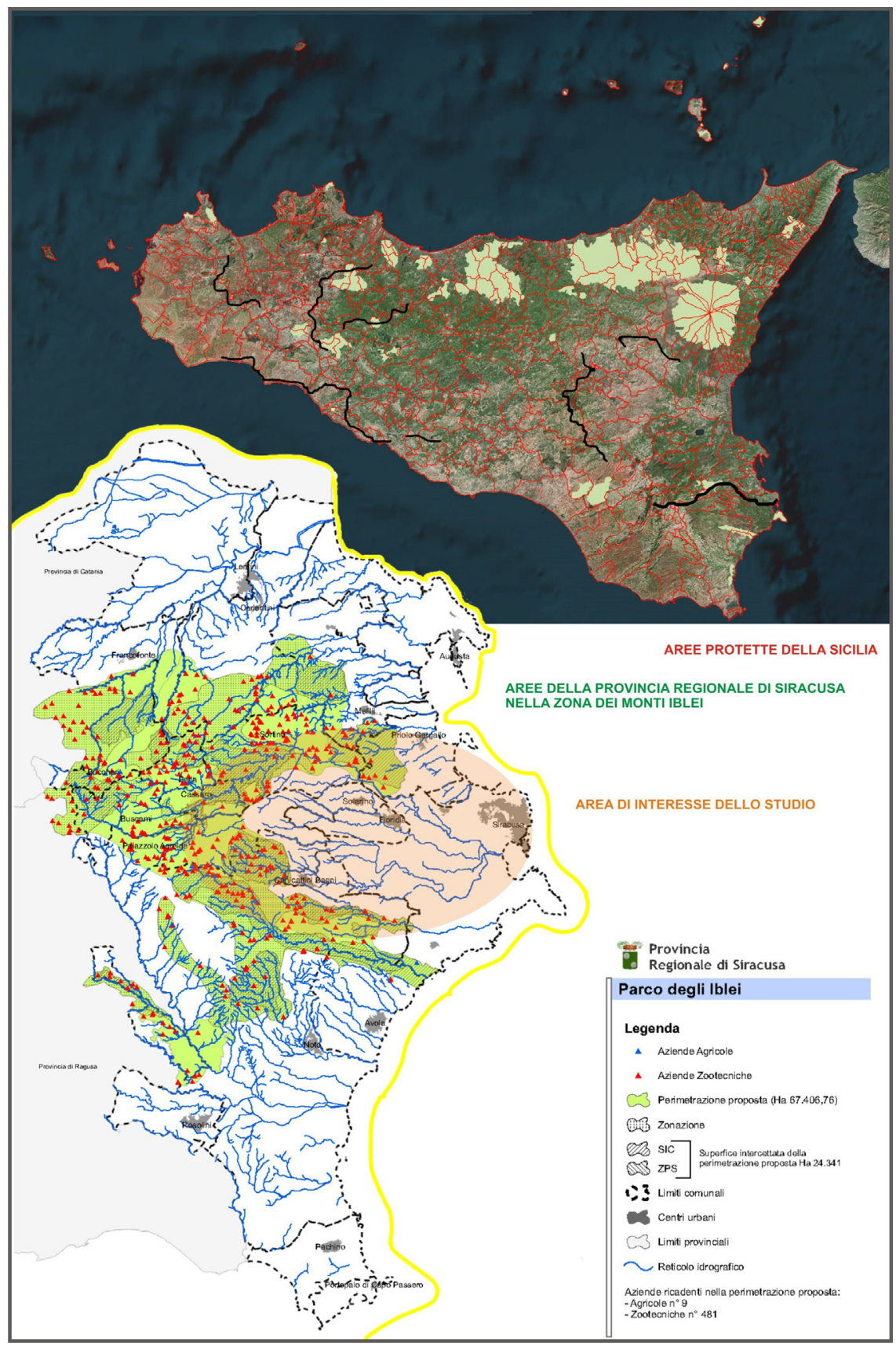

Figure 1: Classification of the study area (sources: Regione Sicilia, Provincia Regionale di Siracusa, Cialdea 2014). 
coastal island systems, which became the symbol of a struggle for the defense of nature. For the first time in the history of the environmental movement, thousands of Sicilian paladins successfully opposed and managed to block the work to build the coastal road which was already underway.

The result of the strong public opposition against the construction of the road in respect of the Sicilian political class, was the promulgation by the Sicily Region, of the first Regional Law 98/81 on protected areas [11], by which the Regional Parliament prescribed the establishment in the near future of regional parks and natural reserves in Sicily and, in Title V, the establishment of the first Sicilian protected area the "Zingaro Natural Reserve" that sanctioned the blockade of the San Vito Lo Capo-Scopello road and preserved one of the most beautiful areas of natural coastal environment and outstanding landscape of the whole of Sicily. A few years later, the Sicilian Parliament promulgated the Regional Law 14/88 [12] that actually created the Etna Park, the first Sicilian Regional Park, two other parks and some nature reserves. Currently, about $10 \%$ of the Sicilian natural heritage is protected, and, over the years, another three regional parks and about eighty natural reserves were set up, plus hundreds of Sites of Community Importance (SCIs) and Special Protection Areas (SPAs) of transnational interest, included in the Natura 2000 network. Among the reserves, in 1997 [13], the Sicilian Parliament established, the natural reserve of "Pantalica, Valle dell'Anapo e Torrente Cava Grande" in order to protect one of the most fascinating natural environments of the entire island, which, in 2005, was also included in the UNESCO World Heritage List [14].

\section{The case study: the "Pantalica, Valle dell'Anapo e Torrente Cava Grande Natural Reserve"}

The case study concerns the protected Natural Reserve named "Pantalica, Valle dell'Anapo e Torrente Cava Grande", managed by the Regional Forestry Board Department, as an example of an area where there is a peculiar feature of the territory, a plurality of types of real and potential gentle mobility, including the ability to cross the territory of the reserve by bike, horse-drawn carriage, on horseback, on foot, through the recovery of a disused railway line and a lot of ancient paths. Within the framework of the "Integrated Plan for sustainable development" of the valleys of Anapo and Cassibile Rivers [15], particular attention was given to gentle traffic in the area (former railroad tracks, royal paths, inter-municipal roads, secondary roads, footpaths, etc.), the connective weave of reserve areas, SCIs, ecological corridors, archaeological sites, scenic sites and areas of interposition of merit among the towns of the district. The reserve offers different natural environments of great ecological value, extremely varied: the aquatic biotope of the river and its streams and springs, the riparian environment, the cliffs' slopes overhanging, the valley plains and the karst caves. In addition to a strong natural character, the protected area presents an important archaeological character, such as the necropolis of Pantalica which, since July 2005, following decisions made during the XXIX Annual Meeting of the World Heritage Committee of UNESCO, was entered in its own right in the list of 
UNESCO World Heritage Sites, named "Syracuse and the Rocky Necropolis of Pantalica". The study area falls within South-eastern Sicily, in the territory of the former province of Syracuse, and is composed of a series of deeply incised river valleys in the carbonate Massif which outcrops in the eastern sector of the Hyblean Plateau. These deep valleys are steep ravines, real canyons, named locally "cave", crossed by the Anapo, Calcinara and Cavagrande Rivers, which has allowed, since the late Bronze Age, the penetration from the coast to the hyblean remote inland and still maintains this peculiarity today. From Syracuse it is possible even today, ascending the valley of the Anapo River, to trace the river inward, to reach the heart of the hyblean plateau, where today several towns and sites of great environmental, historical and archaeological interest, must be visited, still barely inserted into the local tourist panorama, regional and international levels, despite the almost decade-long UNESCO recognition. In the territory of the town of Sortino, inside the archeological site of Pantalica, is located the Europe's largest prehistoric necropolis, consisting of over 5000 tombs in with rock-cut chamber tombs or locally named "grotticella" (Figure 2(a)) dug from the Sicanians along rocky crags overhanging, generally quite visible at the confluence of the valleys of Anapo and of Calcinara Rivers, built at different periods between 1270 and $730 \mathrm{BC}$, when the first Greek colonists founded their earliest colonies along the east coast of the island. In the area of the necropolis there are three extensive Byzantine cave inhabited complexes called Saint Micidario, Saint Nicolicchio and Cavetta, which cherish interesting examples of Byzantine and medieval fresco paintings made on the limestone rocks. The July 25, 1997, Decree No. 482, is established by the Sicilian Region, the Natural Reserve "Pantalica, Valle dell'Anapo e Torrente Cava Grande" that extends over an area of 3,712 hectares to protect one of the landscapes and unique natural environment of the island. The territory of the protected area is managed by the Regional Forestry Board Department which, in recent years has progressively enhanced the use of gentle mobility, thus preventing access by motor vehicle, closing with two gates part of the disused railway line and turning it into one of the most interesting and

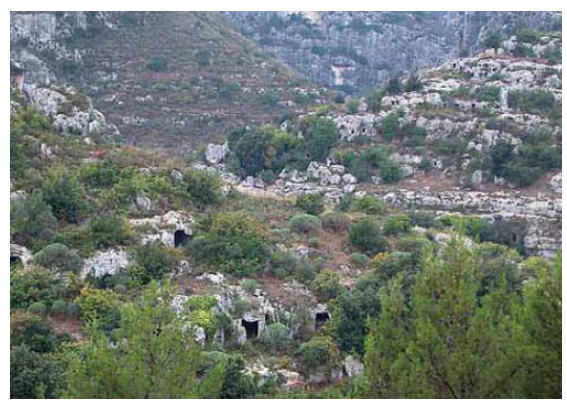

(a)

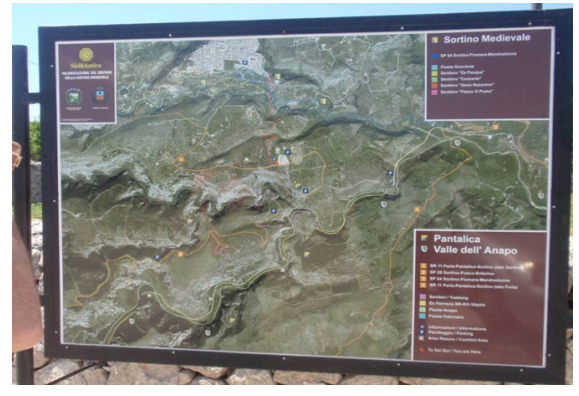

(b)

Figure 2: (a) Rock-cut chamber tombs excavated on the cliffs of Calcinara River; (b) Illustrative panel of secondary roads and footpaths of the Natural Reserve (photos: Sandro Privitera). 
spectacular greenways that has become a favorite place for thousands of walkers and cyclists (Figure 2(b)). However, the Regional Forestry Board Department developed and maintained an extensive network of trails which allow visitors to move easily within the protected area and descend safely to the bottom of the valleys and/or rising up on the plateau. In particular, near the entrance of Ferla, at the visitors' centre a free daily service of mountain bike and helmet rental has been organized in order to discover the land of the Anapo Valley on two wheels, to limit the presence of motor vehicles and encouraging gentle mobility without any emission of exhaust gases, noises and $\mathrm{CO}_{2}$. Even a map of fruition of the reserve was published by the Regional Forestry Board Department, allowing hikers to move easily along the network of trails and paths in the valley area.

\section{The old railways as greenway}

The recovery project of the disused railway path has been the subject of nationwide interest for already quite some time. In 1998, a national law was passed for the financing of the construction of urban and extra-urban cycle lanes as a way of reducing the environmental impact and pollution, with the aim of reducing motorized mobility.

At the same time, the REVERMED European Program was approved [16] which provides the development of routes and the implementation of pilot actions relating to definition of strategies for the creation of a network of greenways in order to encourage non-motorized mobility between regions of the Western Mediterranean area. Recently, the Italian State Railways Company took to heart the concepts of social responsibility and sustainability as guiding principles of its strategic programs, in order to contribute to the development of the country through a network of rail transport which was characterized by fairness and a commitment to greater social cohesion [16-18]. The study carried out in 2001 by the Italian Greenways Association for the exploitation of railway lines that are not used by realization of greenways has marked an important milestone in the maturation of a broader sustainable mobility vision [19]. Attention to the recovery of abandoned and underutilized rail tracks is a political line that can also be an opportunity to create new spaces for socialization. This policy may generate even development opportunities with a new mode of tourism.

The 2008 Financial Law [20] has established a fund of two million of euros to start a program of enhancement and rehabilitation of disused railways. The transformation of abandoned railways into greenways complies with certain technical requirements. The most important is that the trail has a constant slope and path. Often these pathways cross territories which have now become parks, with the possibility of utilization by the user linked to green tourism and can be used by foot, bicycle and even by people with disabilities. Another way to regain an ancient means of locomotion pursuing a new travel mode, combining the old and the new, the eternal theme of the trip with the new sensitivity to the environment. 
Sicily has a number of abandoned railway lines to be reconverted in cycling travel itineraries that connect places of high landscape and cultural significance [17]. The Sicilian climate represents an opportunity for cycling tourism in addition to landscapes, cultural resources and food on the Island.

The development of a cycle network involving the reuse of these abandoned lines is also a great opportunity for the conservation and valorization of the cultural heritage represented by it. Also, the conversion of the rail lines into greenways and cycling lines has many advantages, such as regular and moderate gradients that are perfectly suited to the needs of ordinary cyclists, in their path with a reduced number of intersections with the main road, the variety of different types of environment crossed, the connection between different urban centers, the restoration of the old train stations as resorts and hotels to set up specialized toll for cyclists, or to be used as museums, maintenance shops.

The attention of the Sicilian Government for this subject was notable. The Regional Transport Department in 2002 presented the law "Measures to promote the development of cycling mobility" [21], which states in art. 6 "The Region in the aim of planning of integrated itineraries, proceeds to identify disused railway routes, for the construction of bike lanes along their path, with the aim of creating a regional cycle network". In addition, the Region drew up the Regional Plan of Non-motorized Mobility [18], in line with European guidelines for the respect for greenways. Sicily was the only Italian region in which the State Railways had to exercise, beyond the ordinary gauge network for the main connections, even a narrow gauge network. In particular, in the area covered by this study, between 1915 and 1922, the "Società Anonima per le Ferrovie Secondarie della Sicilia" realized the railway line Siracusa-Ragusa-Vizzini, with a total length of approximately 124 kilometers from the coast of Syracuse, allowed the connection with different cities and towns of the interior. After the initial failure, due to the orography of the territory, haunted with distant stations by its location, the construction of a trunk to service the port of Syracuse, it relaunched the fortunes, thanks to the transport of natural rock asphalt bitumen from the Ragusa quarries. After WWII, the Italian new policy would facilitate road transport, causing the end of the operation on the two branches from Ragusa and Giarratana to Vizzini (February 18, 1949), followed by the final closure (June 30, 1956) and subsequent dismantling. Unfortunately, after many twists and turns with no apparent reason, on June 30,1956, despite the high number of passengers, the railway was finally decommissioned, leaving total isolation in the valley of the Anapo River, which until then could be an easy destination for tourists, travellers, scholars and archaeologists; de facto reducing the great economic potential that the Valley and the necropolis of Pantalica could have represented after World War II, as an important flywheel for the local economy. With the abovementioned 2008 Financial Law, the restoration of the railway line of the Anapo valley was funded. The Siracusa-Ragusa-Vizzini railway is critical in the hyblean territorial context. First of all, for historical reasons, which remain in the still-remembered affectionate appellatives testimony, for example "The train of Mr. Ciccio Piecura" (Pavone); secondly, it is an intimate and unique window on: the wild gorges eroded by the Anapo River, the rural area of 
Giarratana, the pine forests of Chiaramonte Gulfi, the Hyblean plateau landscape, the vast panorama of Vizzini, all typical contexts, and backed by the artistic interest of destinations (some of which are part of the UNESCO Heritage List), and naturalistic interest.

\section{Conclusions and perspectives}

The example of the study area is significant under many aspects, especially related to the willingness expressed by the planning documents. This paper confirms the multiplicity of historical paths that concern the regional territory and the desire to connect them more and more to a sustainable fruition.

In fact, in order to reconstruct the railway route, in particular in the trunk that crosses the Natural Reserve (Figure 3), it is possible to detect the elements of interest and this case study is relevant especially for the evaluation of the landscape values into a place of great beauty. Moreover, this approach methodology is part of alarger ongoing research at the Laboratory L.A.Co.S.T.A aimed at drafting the new Landscape Plan, entrusted by the Molise Region through an Agreement in force. It tends to identify a network of links that go to intrude on natural paths, on ancient paths such as "tratturi" or "trazzere" country paths, and it is able to connect, in a way, a series of thematic landscape resources, historical and cultural sites in the region in order to optimize its use and give a new impulse to green tourism activities. This network should certainly be connected to a broader regional infrastructure system in order to identify new points of interconnection and exchange. To compare the potential of the region with other Italian regions, territorial contexts allow us to focus on the methods of approach to the introduction of sustainable mobility, which network is capable of making all system resources present in the area and that, therefore, can become a new engine of growth. Also, in recent years, studies have been undertaken and the methodology has been refined; the verification several times addressing the approach to the study of protected areas [22-26].

In the examined case of Sicily, a number of different policy instruments were put in place. Since the late 90s, several spatial planning instruments were developed, starting with the Territorial Pact in the Province of Syracuse, enacted with resolution CIPE of $12 / 18 / 96$, which was the first approved pact in Italy. Between the lines of growth emerges one that will encourage the activities linked to the tourist industry. However, in those years, the Integrated Area Plan for the Province of Siracusa was set up, which formulates a chart of cultural resources and identifies specific areas of intervention for the most susceptible areas of tourism development.

Also, the area of the Anapo River is directly affected by certain tools, such as the Province of Syracuse made up of a public private consortium located in the Province and aimed at promoting local agricultural development, in particular to take advantage of EU financing under the LEADER programme. However, it was through the Strategic Plans that new territorial policies were developed. They have been designed for three districts, namely that of Syracuse (including the urban area), of Avola and above all that of Augusta. 


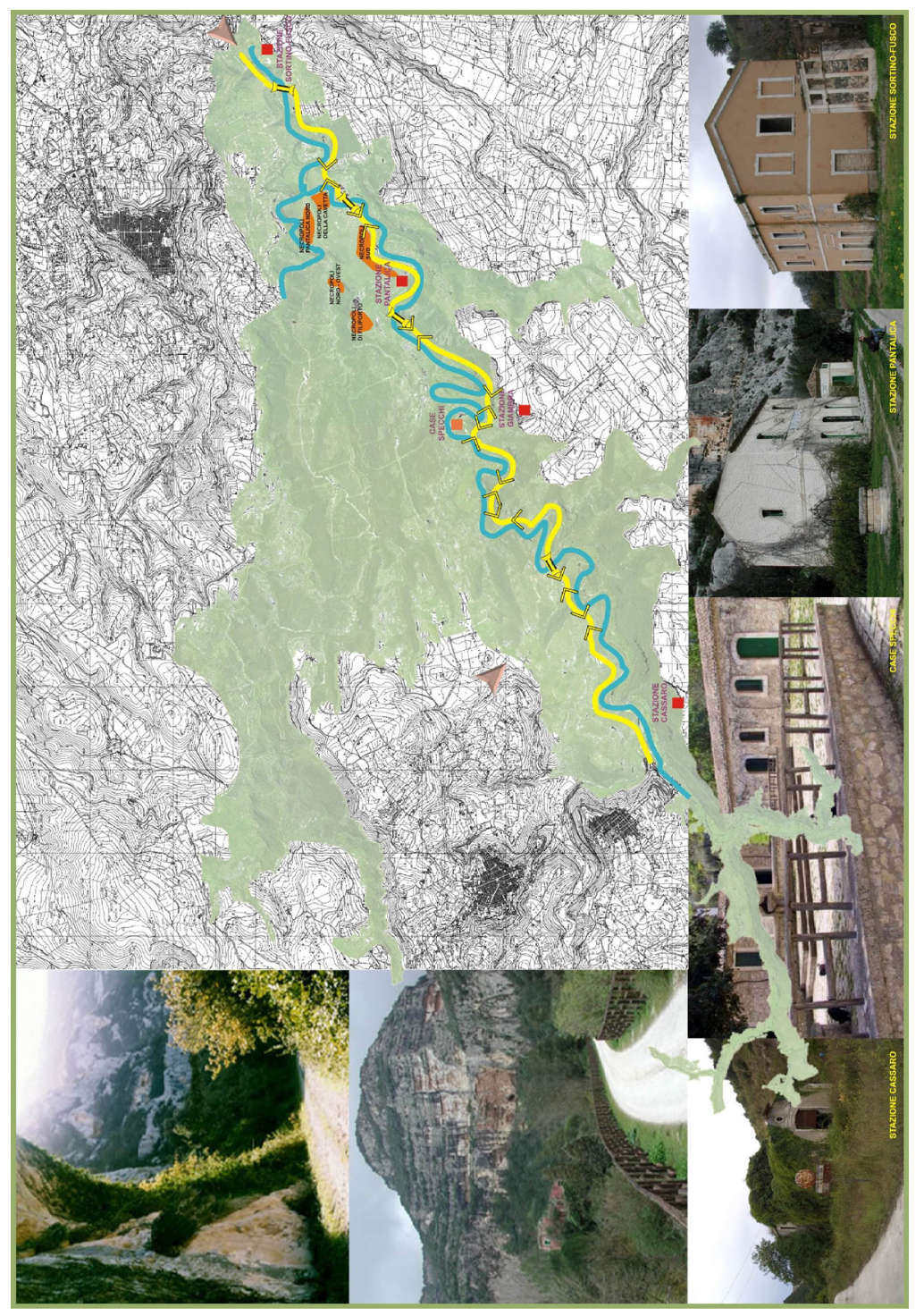

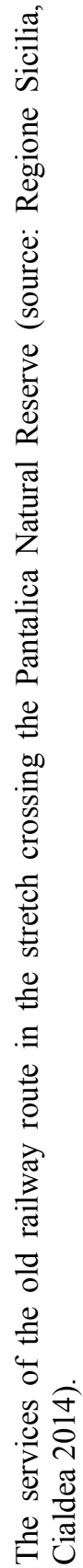

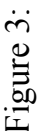


It is just the latter district that involves the municipalities which are involved in the Strategic Plan "Thapsos Megara - Hyblon Tukles" with Augusta which is the lead partner and the other municipalities of the district [27].

The purpose of the plan was to locate the coherence in strategies aimed at local development in an area, which is the Province of Syracuse, abundantly endowed with natural and cultural resources in order to build the Touristic Territorial District "Siracusa and Noto Valley" [10]. Among the actions taken are both the "Reactivation of the ancient crossing of the Calcinara North city gate of the necropolis of Pantalica" in Sortino, and "the environmental and landscape recovery of the West Gate of the necropolis of Pantalica", in Ferla.

In addition, the previously mentioned Development Plan of Broad Area, activated by the Integrated Sustainable Development Plan by the Development Agency GAL Val d'Anapo, has worked in order to set up a general reference framework for the sustainable development of the area, which was common for all instruments of implementation and connect the interdependent action plan with the instruments of government of the territory. The development process has made it possible to identify and enable the planning of a social-economic local development "participatory bottom-up democraticy" and, for this reason realistic, as it is based on real local potential and the real needs of conscious people that have an interest in that. This laid down the construction of an "inner and disadvantaged" area and an integrated, productive district with strong environmental significance and historical-cultural importance, in respect of an integrated plan for sustainable development which is shared by the community and involved different competent institutional levels" [15]. Even in this case, interventions were performed inside the Reserve, such as the construction of facilities for accessing the reserve area in a regulated way, for the infrastructure network services of the Reserve area and the reconversion of the former stations of Pantalica and Giambra along with the path rail which is the object of our study. Another initiative which deserves a mention is the proposal for the merger of candidacy of the Union of the Municipalities "Valle degli lblei" as an optimal territorial basin different from the provincial dimension, pursuant to Circular No. 1 of May 16, 2012. Also, in this case the Technical Report on the motivations of the "territorial differentiation" is of particular interest. It lists the indicators of territorial differentiation (location and size of the basin, and its demographical and geomorphological description) as well as indicators of socioeconomic differentiation (including the cited presence of sites of natural, historical and artistic interest and among them, also the common feature destroyed by the earthquake of 1693, which was rebuilt and retained the eighteenth-century plan.

Much more can be deepened on the themes of the interventions through the new tools related to new forms of planning. This case study has provided interesting elements of reflection and inspiration because it concerns a reference area characterized by a strong tourist industry, which is well-suited to the construction of a tourist package linked to the value of cultural and environmental goods. 


\section{References}

[1] Regione Sicilia, Decreto Assessoriale 11 aprile 1991 Dichiarazione di notevole interesse pubblico dell'area del Monte Climiti e della Valle dell'Anapo. (GU Serie Generale n.119 del 23-5-1992).

[2] Regione Sicilia, Decreto Assessoriale 14 ottobre 1993, Dichiarazione di notevole interesse pubblico della zona circostante il fiume Ciane ricadente nel comune di Siracusa. (GU Serie Generale n.165 del 16-7-1994).

[3] Regione Sicilia, Decreto Assessoriale 24 marzo 1994 Dichiarazione di notevole interesse pubblico dell'area interessante l'alto vulcanico di Monte S. Venere nei comuni di Ferla e Carlentini e vincolo di immodificabilita' temporanea. (GU n.260 del 7-11-1994).

[4] Regione Sicilia, Decreto Assessoriale 12 maggio 1998, Dichiarazione di notevole interesse pubblico dell'Alta valle dell'Anapo, ricadente nei comuni di Buccheri, Buscemi, Carlentini, Cassaro, Ferla, Palazzolo Acreide e Sortino. (GU Serie Generale n.224 del 25-9-1998).

[5] Regione Sicilia, Decreto Assessoriale 28 dicembre 1999, Vincolo paesaggistico sull'area comprendente la Valle del fiume Cassibile, Bosco di Bauli', Cava Giorgia, Cava Sture, Cava della Contessa. Gazzetta n. 33 del 10 febbraio 2000.

[6] Regione Sicilia, Decreto 26 luglio 2000, Dichiarazione di notevole interesse pubblico dell'area comprendente la valle del fiume Tellaro e dei torrenti Tellesimo e Prainito della Cava Scardina,Cava Grande, Cava Lazzaro, Cava Croce Santa, Cava Scalarangio, ricadente nei comuni di Rosolini, Noto e Palazzolo Acreide.

[7] Provincia Regionale di Siracusa, Parco Nazionale degli Iblei. Proposta di azione, luglio 2010.

[8] Provincia Regionale di Siracusa, Parco Nazionale degli Iblei. Conclusioni istruttorie, novembre 2010.

[9] MiBAC,Siciliaionica, Pantalica, ovvero Luogo delle Grotte, 2011.

[10] Regione Sicilia, Assessorato Turismo, Sport e Spettacolo, Provincia Regionale di Siracusa Distretto turistico territoriale (D.A. n. 3 del 16 febbraio 2010) Siracusa e Val di Noto, 2010.

[11] Regione Sicilia, Legge Regionale 6 maggio 1981, n. 98, modificata ed integrata dalla 9 agosto 1988, n. 14 Norme per l'istituzione nella Regione siciliana di parchi e riserve naturali (Pubblicata sulla Gazz. Uff. Reg. Sic. 9 maggio 1981, n. 23, S.O), 1981.

[12] Regione Sicilia, Legge Regionale 9 agosto 1988, n. 14 G.U.R.S. 13 agosto 1988, n. 35 Modifiche ed integrazioni alla legge regionale 6 maggio 1981, n. 98: "Norme per l'istituzione nella Regione di parchi e riserve naturali" 1988.

[13] Regione Sicilia, Decreto 25 luglio 1997, n. 482 Supplemento Ordinario n. 1 G.U.R.S. 17 gennaio 1998, n. 3, Istituzione della riserva naturale Pantalica, Valle dell'Anapo e Torrente Cava Grande, ricadente nel territorio dei comuni di Sortino, Ferla, Cassaro, Buscemi e Palazzolo Acreide. 1997. 
[14] UNESCO, Siracusa e le Necropoli rupestri di Pantalica, Anno di iscrizione nella World Heritage List: 2005.

[15] GAL Agenzia di Sviluppo Val d'Anapo, P.I.S.S. Piano Integrato per lo Sviluppo Sostenibile del Comprensorio Val d'Anapo U.T.R.A.S. (Unità Territoriale di Recupero Ambientale e Storico-culturale) delle Valli dell'Anapo e del Cassibile (1998 - processo in atto), 1998.

[16] Regione Sicilia, Dipartimento Regionale Trasporti e Comunicazioni, Studio per la realizzazione di una rete di percorsi verdi dedicata alla mobilità non motorizzata in Sicilia, Progetto REVER MED, Programma Interreg IIIB, 2004.

[17] Regione Sicilia, Dipartimento Regionale Trasporti e Comunicazioni, La valorizzazione delle linee ferroviarie non utilizzate attraverso la creazione di un sistema di greenways, Ferrovie dello Stato S.p.a. - Direzione Generale di Gruppo per le Risorse Umane Politiche Ambientali e della Sicurezza del Lavoro; ISFORT, 20 ottobre 2003.

[18] Regione Sicilia, Decreto 6 giugno 2005. Piano della mobilità non motorizzata in Sicilia. Pubblicato sulla Gazzetta Ufficiale Regione Siciliana - supplemento ordinario n. 28 del $1^{\circ}$ Luglio 2005.

[19] ISFORT, Ferrovie, territorio e sistema di greenways, Roma, maggio 2004.

[20] Legge 24 dicembre 2007, n. 244, Disposizioni per la formazione del bilancio annuale e pluriennale dello Stato (legge finanziaria 2008 in G.U. n. 300 del 28 dicembre 2007).

[21] Regione Sicilia, Schema di disegno di legge "Interventi per favorire lo sviluppo della mobilità ciclistica”, 2002.

[22] Cialdea, D., Il Molise terra di transito. I tratturi come modello di sviluppo del territorio: Campobasso. Arti Grafiche La Regione, 2007.

[23] Cialdea, D., Privitera S., The state of the environment on the Adriatic coast: elements of value and conflict. In: Proceedings of the 13th National Meeting of APDR University of Azores, Angra do Heroísmo, Azores, Portugal, 5 to 7 July 2007 - 1st Congress of Nature Management Conservation 1st Portuguese Speaking Countries Meeting for Regional Science - Recreating and Valuing Territories - Session 2 Nature conservation and regional development,. Angra do Heroísmo, Azores, Portugal, 5-7 July 2007, Paper n. 241, pubblicato su web www.apdr.pt, 2007.

[24] Cialdea, D., A new landscape planning approach in areas with a strongly rural matrix. In: Campagna M., De Montis A., Isola F., Lai, S., Pira C., Zoppi C. (edited by). Planning Support Tools: Policy Analysis, Implementation and Evaluation. Chap. 5, pp. 453-464, Milano: Franco Angeli, 2012.

[25] Cialdea, D., Maccarone A., Territorial diachronic maps for the Regional Landscape Plan. In: (a cura di): Campagna M., De Montis A., Isola F., Lai, S., Pira C., Zoppi, C., (edited by), Planning Support Tools: Policy Analysis, Implementation and Evaluation. Chap. 4, pp. 386-398, Milano: Franco Angeli, 2012. 
[26] Cialdea, D., Maccarone, A., Il Piano Paesaggistico Regionale e la mobilità sostenibile. PLANUM, vol. 27, pp. 23-31, 2013.

[27] P.I.T. Hyblon - Tukles, Progetto Integrato Territoriale, Il Processo di Sviluppo in Atto nell'area Hyblon-Tukles s.d., 2007. 